\title{
ANALISIS PERBANDINGAN METODE PERHITUNGAN PPh 21 PADA KARYAWAN PT ISTAKA KARYA (PERSERO)
}

\author{
Baso R 1, Misbah 2), Sumarni S3) \\ Jl. A. P. Pettarani No. 72 D1, Tamamaung, Panakkukang, Kota Makassar, Sulawesi Selatan \\ E-Mail: sumarnisarong@wirabhaktimakassar.ac.id
}

DOI: https://doi.org/10.35606/jabm.v28i1.810

\section{Akuntansi Bisnis dan Manajemen (ABM),}

Vol. 28

No. 01

Halaman 45-54

Bulan April, Tahun 2021

ISSN 0854-4190

E-ISSN 2685-3965

\section{Informasi Artikel}

Tanggal Masuk:

3 Maret 2021

Tanggal Revisi:

31 Maret 2021

Tanggal Diterima:

06 April 2021

\section{Abstract}

The purpose of this study was to determine the comparison of the use of the calculation of the net basis method and the gross up method in calculating PPh 21 for the employees of PT Istaka Karya (Persero). This study uses quantitative research using comparative descriptive analysis techniques. The research object at PT Istaka Karya (Persero). The results show that the calculation of PPh 21 PT Istaka Karya (Persero) uses the gross method, namely the employees bear their own PPh 21. The most efficient method used in calculating PPh 21 PT Istaka Karya (Persero) from the three methods being compared is the gross up method. Because it benefits both parties, namely employees and also the company. However, if viewed from the nominal side, the tax is smaller if the company uses the net basis metho.

Keywords: PPh 21; gross method; net basis method; gross up method

\section{Abstrak}

Tujuan penelitian ini adalah untuk mengetahui perbandingan penggunaan perhitungan metode net basis dan metode gross up dalam menghitung PPh 21 pada Karyawan PT Istaka Karya (Persero). Penelitian ini menggunakan penelitian kuantitatif dengan menggunakan teknik analisis deskriptif komparatif. Obyek penelitian pada PT Istaka Karya (Persero). Hasil penelitian menunjukan bahwa perhitungan PPh 21 PT Istaka Karya (Persero) menggunakan metode gross, yaitu karyawan menanggung sendiri PPh 21. Metode yang paling efisien yang digunakan dalam menghitung PPh 21 PT Istaka Karya (Persero) dari ke tiga metode yang dibandingkan yaitu metode gross up karena menguntungkan kedua belah pihak yaitu karyawan dan juga perusahaan. Tetapi jika dilihat pada sisi nominal pajak lebih kecil jika perusahaan menggunakan metode net basis.

Keywords: PPh 21; metode gross; metode net basi; , metode gross up. 


\section{PENDAHULUAN}

Pajak memiliki peranan yang signifikan dalam kehidupan bernegara, khususnya pembangunan, karena pajak merupakan sumber pendapatan negara yang digunakan untuk membiayai seluruh pengeluaran, termasuk untuk pembangunan (Rioni, Saraswati, \& Junawan, 2019). Salah satu jenis pajak yang dibebankan negara kepada wajib pajak adalah PPh. Pasal 21. PPh Pasal 21 merupakan pajak yang dikenakan kepada wajib pajak orang pribadi dalam negeri atas penghasilan yang terkait dengan pekerjaan, jasa atau kegiatan. Penghasilan yang dimaksud meliputi upah, gaji, honorarium, tunjangan, dan pembayaran lain dengan nama dan dalam bentuk apapun (Resmi, 2019). Metode yang dapat digunakan untuk menghitung PPh 21 (PPh atas penghasilan karyawan) dapat menggunakan salah satu alternatif dari tiga jenis metode yang ada yaitu, (1) metode Gross, yang merupakan pemotongan pajak berdasarkan tarif yang dibebankan kepada karyawan; (2) metode gross up merupakan salah satu metode yang dapat digunakan oleh perusahaan untuk memanfaatkan perbedaan tarif pajak antara badan dan orang pribadi, karena tunjangan pajak PPh 21 yang diberikan kepada karyawan akan menambah Penghasilam Kena Pajak (PKP) dari karyawan yang hanya sedikit mengalami kenaikan dan akan mengurangi PKP badan; (3) metode Net basis merupakan metode dimana perusahaan atau pemberi kerja menanggung beban pajak karyawanya (Rioni et al., 2019; Setiawan, 2017).

Hasil penelitian Vridag (2015) menunjukan bahwa penerapan metode gross up akan memberikan keuntungan bagi kedua pihak baik karyawan maupun perusahaan dibandingkan jika menggunakan metode net basis. Selain itu menurut (Marfiana, 2019), penerapan metode gross-up dalam perhitungan PPh pasal 21 hanya optimal apabila diterapkan kepada pegawai yang memiliki penghasilan pada lapisan tarif pajak di bawah tarif PPh Badan, namun jika diterapkan pada pegawai yang terkena lapisan tarif pajak tertingi, metode gross-up tidak memberikan manfaat bagi wajib pajak. Di sisi lain terkait pemberian insentif berupa tunjangan pajak, dapat memberikan motivasi bagi pegawai, karena tax home pay yang diterima tidak lagi dikurangkan oleh PPh Pasal 21.

Hasil Penelitian lainnya disampaikan oleh Ermaya and Rantererung (2016) yang menyampaikan bahwa untuk menekan penurunan laba PT. Kimia Farma (Persero) Tbk. Plant Bandung, maka perusahaan melakukan alternatif perencanaan PPh pasal 21 dengan menggunakan metode Gross-up dan perhitungan ini tepat bagi perusahaan yang menanggung seluruh pajak penghasilan bagi karyawan. Hasil penelitian Nabilah, Mayowan, and Hapsari (2016) menunjukkan bahwa penerapan perencanaan pajak menggunakan Gross Up Method merupakan yang paling tepat bagi PT Z. Penerapan Gross Up Method terbukti berhasil menurunkan Pajak Penghasilan perusahaan serta mampu melakukan penghematan Pajak Penghasilan juga mengakibatkan laba komersial perusahaan setelah pajak meningkat (Arham, 2016).

Berdasarkan hasil penelitian yang telah diuraikan sebelumnya, maka penelitian ini merupakan replikasi dari penelitian terdahulu yang tujuannya adalah untuk mengetahui dan mendeskripsikan metode yang diterapkan oleh PT Istaka Karya (Persero) dan membuat perbandingan jika perusahaan menerapkan metode net basis dan metode gross up dalam perhitungan PPh Pasal 21. 


\section{METODE PENELITIAN}

Jenis penelitian ini adalah kuantitatif, yaitu penelitian yang mendeskripsikan keadaan yang menjadi fokus dalam penelitian berdasarkan data berupa angka yang telah dikumpulkan (Widayat, 2014). Jenis data yang digunakan adalah data sekunder, berupa data keuangan perusahaan yang meliputi rekapitulasi gaji karyawan, laporan SPT massa, daftar pemotongan PPh Pasal 21. Data diperoleh menggunakan metode dokumentasi, yaitu berdasarkan rekapitulasi gaji karyawan, laporan SPT massa, dan daftar pemotongan PPh Pasal 21 yang dianggap berhubungan dengan topik penelitian.

Setelah data yang diperlukan terkumpul, selanjutnya dilakukan analisis dengan pendekatan analisis deskriptif yaitu menggambarkan apa yang telah dilakukan oleh perusahaan dan membandingkan perhitungan pemotongan yang digunakan oleh perusahaan dengan metode lainnya yaitu metode net basis dan gross up. Dari hasil perbandingan tersebut dapat diketahui metode manakah yang lebih efisien dan dapat dapat digunakan oleh perusahaan.

\section{HASIL DAN PEMBAHASAN}

Penelitian ini dilaksanakan di Kota Jakarta Selatan, tepatnya pada PT Istaka Karya (Persero), Kebayoran Baru, Jakarta Selatan 12160. PT Istaka Karya (Persero) adalah perusahaan milik Negara yang bergerak di bidang jasa konstruksi umum dan pada awalnya didirikan dengan nama PT ICCI (Indonesia Consortium of Construction Industries) yang terdiri dari delapan belas perusahaan kontraktor utama di Indonesia. Tekadnya dalam bidang konstruksi ditunjukan dalam pencapaian pada tahun 1985, termasuk keberhasilannya dalam menangani berbagai proyek senilai US \$ 300 juta di Arab Saudi. Dengan semua pengalaman dan sumber daya manusia yang dimilki oleh Konsorsium, pada tanggal 11 April 1981, Pemerintah memutuskan membubarkan Konsorsium dan meresmikan perusahaan bernama PT Istaka Karya (Persero). Perusahaan yang baru didirikan ini dilegalkan dengan akta pendirian No. 011989 , yang diumumkan dalam Lembaran Berita Negara No. 69 tertanggal 28 Agustus 1986. Keputusan di atas didasarkan pada peraturan pemerintah yang khusus ditujukan untuk perusahaan milik Negara. PT. Istaka Karya (Persero) telah mengembangkan dan menerapkan konstruksi dengan standar internasil serta telaah mengopereasikan teknik manajamen terkomuputerisasi. Langkah PT Istaka Karya (Persero) di kenal di skala nasional dan internasional, pada tahun 1997 PT Istaka Karya (Persero) menerima Sertifikat Sistem Mutu ISO-9002 dari SGS ICS United Kingdom, yang kemudian diperbarui ke Sistem Manajemen Kualitas ISO-9002:2000 pada tahun 2003, pada tahun 2002. Presiden Repoblik Indonesia memberikan medali emas untuk keberhasilan perusahaan dalam Sistem Manajemen Keselamatan dan Kesehatan Kerja. Pada Tahun 2008 PT Istaka Karya (Persero) juga menerima Sistem Manajemen OHSAS 18001: 2007 dan Lingkungan ISO 1400: 2004 dari WQA dengan visi "Menjadi perusahaan industri konstruksi, yang kokoh dan terpercaya di Indonesia, dengan layanan dan produk terbaik".

Data yang digunakan dalam penelitian ini adalah data sekunder berupa data keuangan perusahaan yang meliputi rekap gaji karyawan, laporan SPT massa, daftar pemotongan PPh Pasal 21. Data diperoleh menggunakan metode dokumentasi, yaitu dengan merangkum rekap gaji karyawan, laporan SPT massa, dan daftar pemotongan PPh Pasal 21 yang dianggap berhubungan dengan penelitian. Setelah data yang 
diperlukan telah terkumpul, selanjutnya dilakukan analisis. Pendekatan teknik analisis yang digunakan adalah dengan menggunakan pendekatan analisis deskriptif yaitu dengan membandingkan antara metode perhitungan pemotongan yang digunakan oleh perusahaan yaitu metode perhitungan Pajak Penghasilan Pasal 21 metode gross dengan metode net basis dan gross up. Dari hasil perbandingan perhitungan tersebut dapat diketahui metode yang manakah yang lebih efisien yang dapat dapat digunakan oleh sisi pihak perusahaan.

Karyawan PT. Istaka Karya (Persero) yang merupakan wajib pajak terdiri dari 26 karyawan. dengan komponen gaji tetap dalam sebulan karyawan terdiri dari Gaji dasar, Tunjangan Struktural, Tunjangan Fungsional, Tunjangan Project Manager, Tunjangan SEM/SOM/SAM, Tunjangan Pelaksanaan Lapangan Lapangan. Pendapatan lain karyawan terdiri dari : Lembur, Tunjangan Proyek, Tunjangan Makan dan Transportasi. Besaran gaji tetap dari 26 karyawan, pendapatan lain serta potongan, disesuaikan dengan jabatan setiap karyawan. Terkait dengan komposisi gaji hanya beberapa karyawan yang mendapatkan tunjungan Struktural yaitu hanya 11 orang yaitu yang menduduki jabatan sebagai Pelaksana Tugas Site Administration Manager (Plt SAM), Pelaksana Tugas Manager Bisnis Konstruksi 3 (Plt. Mnj PBK-3 ), Pelaksana Tugas Site Operation Manager (Plt SOM), Project Manager (PM), Pelaksana Jabatan Kepala Divisi Keuangan (Pj. Kadiv Keuangan), Kepala Divisi Operasi I (Kadiv operasi I), Pelaksana Manager Pengendalian (Plt Mnj. Pengendalian), Auditor Keuangan, Manajer Keselamatan dan Kesehatan Kerja (Mnj. HSE), Manager Pengendalian, (Mnj Pengendalian), Manajer Pengembangan Bisnis Konstruksi I (Mnj. PBK-I). Terkait dengan tunjangan fungsional hanya 3 orang karyawan yang menerima yaitu karyawan menduduki jabatan sebagai Sekretaris Perusahaan, Kesejahteraan dan Adminstrasi Karyawan. Sedangkan untuk tunjangan Site Administration Manager (SAM) hanya 1 orang dari 26 orang karyawan berdasarkan yaitu yang menduduki jabatan Pelaksana Jabatan Site Administration Manager.

Pendapatan lain-lain dari seluruh karyawan PT Istaka Karya (Persero) terdiri dari Pendapatan lembur selama 1 bulan hanya diperoleh karyawan yang dengan posisi jabatan sebagai staf legal, sementara karyawan lainnya tidak mendapatkan tunjangan lembur. Tunjangan proyek bagi seluruh karyawan untuk bulan Januari, seluruh karyawan tidak memperoleh tunjangan tersebut. Tunjangan makan dan transportasi merupakan tunjangan tetap bagi seluruh karyawan dan nominalnya dipengaruhi oleh jumlah presensi kehadiran masing-masing karyawan. Berikut tabel status dan penghasilan Karyawan Bulan Januari s.d Juni 2019 yang bersumber dari PT. Istaka Karya (Persero)

Tabel. 1

Status dan Penghasilan Karyawan Bulan Januari s.d Juni 2019

\begin{tabular}{crcccc}
\hline No. & Nama Wajib Pajak & Status & $\begin{array}{c}\text { Gaji Tetap, } \\
\text { Pendapatan Lain, } \\
\text { Potongan }\end{array}$ & $\begin{array}{c}\text { Komponen } \\
\text { Gaji }\end{array}$ & $\begin{array}{c}\text { Pendapatan } \\
\text { Lain }\end{array}$ \\
\hline A & B & & C & D & F \\
\hline 1 & ASW & TK & $38,001,504$ & $32,125,260$ & $6,840,000$ \\
2 & AD & TK & $46,828,152$ & $43,111,500$ & $5,400,000$ \\
3 & NCU & TK & $33,350,000$ & $27,000,000$ & $7,160,000$ \\
\hline
\end{tabular}




\begin{tabular}{rlrrrr}
\hline 4 & RA & TK & $35,147,143$ & $26,044,949$ & $11,844,270$ \\
5 & DZ & TK & $32,929,344$ & $27,356,496$ & $6,630,000$ \\
6 & AS & K0 & $37,937,460$ & $24,018,000$ & $14,880,000$ \\
7 & AMP & K0 & $60,629,562$ & $48,317,484$ & $13,950,000$ \\
8 & IY & K1 & $52,444,122$ & $41,070,000$ & $13,020,000$ \\
9 & YAT & K1 & $44,058,726$ & $38,988,252$ & $6,630,000$ \\
10 & BKA & K1 & $67,453,824$ & $66,410,472$ & $2,550,000$ \\
11 & AS & K1 & $61,019,562$ & $48,317,484$ & $13,950,000$ \\
12 & ADK & K1 & $93,204,510$ & $70,908,024$ & $24,180,000$ \\
13 & RU & K2 & $126,216,960$ & $119,370,000$ & $10,200,000$ \\
14 & WP & K2 & $144,039,240$ & $137,556,000$ & $10,200,000$ \\
15 & NP & K2 & $68,830,254$ & $65,549,688$ & $4,770,000$ \\
16 & AW & K2 & $40,785,870$ & $35,941,056$ & $6,240,000$ \\
17 & JM & K2 & $106,067,400$ & $98,748,000$ & $10,260,000$ \\
18 & IS & K3 & $90,373,080$ & $78,264,000$ & $15,120,000$ \\
19 & HP & K3 & $114,751,440$ & $100,446,000$ & $17,280,000$ \\
20 & S & K3 & $63,372,480$ & $52,794,000$ & $12,600,000$ \\
21 & EPS & K3 & $49,061,196$ & $38,484,000$ & $10,920,000$ \\
22 & M & K3 & $114,357,480$ & $100,044,000$ & $17,280,000$ \\
\hline JUMLAH & & $1,52,859,309$ & $1,320,864,665$ & $241,904,270$ \\
\hline
\end{tabular}

Berdasarkan Tabel 2 di atas menunjukan bahwa status karyawan menunjukkan 5 orang yang berstatus TK, 2 orang K0, 5 orang K2, 5 orang K3. Rekapitulasi penghasilan karyawan PT Istaka Karya (persero) Bulan Januari sampai dengan Juni 2019 terkait gaji tetap, pendapatan lain, potongan adalah sebesar $\operatorname{Rp} 1,520,859,309$, komponen gaji adalah sebesar $\operatorname{Rp} 1,320,864,66$, sedangkan pendapatan lain adalah sebesar $\mathrm{Rp}$ $241,904,270$.

\section{Metode Perhitungan PPh Pasal 21 Pada PT Istaka Karya (Persero)}

Perhitungan PPh Pasal 21 Pada PT Istaka Karya (Persero) menggunakan metode gross. Metode gross merupakan metode yang dipilih oleh perusahaan dalam menghitung pajak karyawan, dimana metode ini tarif pajak dibebankan kepada karyawan sebagai wajib pajak. Perhitungan PPh Pasal 21 metode gross untuk bulan Januari 2019 dari 26 karyawan PT Istaka Karya (Persero) dengan status wajib pajak dari Tidak Kawin (TK), Kawin tanpa tanggungan (K0), Kawin dengan tanggungan 1 orang (K1), Kawin dengan tanggungan 2 orang (K2) dan Kawin dengan tanggungan 3 orang (K3). Untuk lebih jelasnya perhitungan PPh Pasal 21 karyawan PT Istaka Karya (Persero) dengan menggunakan metode gross menunjukan bahwa PPh Pasal 21 metode gross terdiri dari nama wajib pajak, status wajib pajak, gaji bruto, potongan yang terdiri dari BPJS Ketenagakerjaan sebesar 7,74\%, biaya jabatan (Maksimal potongan sebesar Rp 500.0000, dana pensiun maksimal Rp 200.000, sementara untuk gaji netto merupakan gaji bruto dikurangi dengan total potongan. Gajo netto setahun merupakan jumlah gaji netto dikalikan 12 bulan. Pendapatan Tidak Kena Pajak selama setahun nominalnya ditentukan dari status wajib pajak. Pendapatan Kena Pajak (PKP) 
selama setahun dihitung dari besarnya gaji netto setahun dikurangi dari PTKP selama setahun. Sehingga perhitungan PPh Pasal 21 setahun dihitung dari persentase 5\% jika penghasilan wajib pajak dengan ketentuan penghasilan selama setahun $1 \mathrm{~s} / \mathrm{d} 50$ juta rupiah sedangkan $15 \%$ jika penghasilan wajib pajak dengan ketentuan penghasilan selama setahun di atas 50 s/d 250 juta rupiah. Jumlah setoran PPh Pasal 21 sebulan berasal dari PPh Pasal 21 setahun dibagi 12 bulan.

\section{Perhitungan PPh Pasal 21 dengan Metode Net Basis}

Perhitungan PPh Pasal 21 dengan metode net, dilakukan dengan tidak memperhitungan PPh Pasal 21 terutang sebagai unsur tambahan penghasilan. Berikut adalah perhitungan penghasilan bruto yang diperoleh karyawan PT Istaka Karya (Persero) Kantor Pusat apabila perusahaan menanngung PPh Pasal 21 terutang, akan tetapi tidak menjadikan tunjangan PPh Pasal 21 sebagai unsur tambahan penghasilan. Menunjukan bahwa PPh Pasal 21 metode net basis terdiri dari nama wajib pajak, status wajib pajak, gaji bruto dari perhitungan metode gross up, tunjangan pajak yang sebagai pengurang gaji bruto karena tidak diakui sebagai tambahan penghasilan, gaji bruto setelah dikurangi tunjangan, pajak potongan yang terdiri dari BPJS Ketenagakerjaan sebesar 7,74\%, biaya jabatan (Maksimal potongan sebesar Rp 500.0000, dana pensiun maksimal $\mathrm{Rp}$ 200.000, sementara untuk gaji netto merupakan gaji bruto dikurangi dengan total potongan. Gaji netto setahun merupakan jumlah gaji netto dikalikan 12 bulan. Pendapatan Tidak Kena Pajak (PTKP) selama setahun nominalnya ditentukan dari status wajib pajak. Pendapatan Kena Pajak (PKP) selama setahun dihitung dari besarnya gaji netto setahun dikurangi dari PTKP selama setahun. Sehingga perhitungan PPh Pasal 21 setahun dihitung dari persentase 5\% jika penghasilan wajib pajak dengan ketentuan penghasilan selama setahun $1 \mathrm{~s} / \mathrm{d} 50$ juta rupiah sedangkan $15 \%$ jika penghasilan wajib pajak dengan ketentuan penghasilan selama setahun di atas 50 s/d 250 juta rupiah. Jumlah setoran PPh Pasal 21 sebulan berasal dari PPh Pasal 21 setahun dibagi 12 bulan.

Perhitungan potongan BPJS Ketenagakerjaan sebesar 7,74\% adalah jumlah total persentase dari BPJS yang terdiri dari potongan BPJS yang di bebankan kepada karyawan sebesar 2,00\% dan dibebankan kepada perusahaan sebesar 5,74\%.

\section{Perhitungan PPh Pasal 21 Metode Gross Up}

Perhitungan PPh Pasal 21 dengan metode gross up, dilakukan dengan perusahaan menanggung PPh Pasal 21 terutang dengan memberikan tunjangan PPh Pasal 21 sebagai unsur tambahan penghasilan. Tunjangan PPh Pasal 21 ditambah dengan unsur penghasilan gaji bruto, setelah itu dikurangi dengan unsur-unsur potongan. Gaji netto adalah hasil dari gaji bruto dikurangi potongan. Gaji netto setahun merupakan hasil dari gaji netto dikalikan 12 bulan. Pendapatan Kena Pajak (PKP) setahun adalah gaji netto setahun dikurangi Penghasilan Tidak Kena Pajak (PTKP), PTKP setahun 
dikalikan dengan persentase pemotongan dan menghasilan PPh Pasal 21 setahun. PPh Pasal 21 setahun dibagi 12 bulan menghasilan nilai pajak sebulan.

Perhitungan PPh Pasal 21 metode gross up untuk bulan Januari 2019 dari 26 karyawan PT Istaka Karya (Persero) dengan status wajib pajak dari Tidak Kawin (TK), Kawin tanpa tanggungan (K0), Kawin dengan tanggungan 1 orang (K1), Kawin dengan tanggungan 2 orang (K2) dan Kawin dengan tanggungan 3 orang (K3). Untuk lebih jelasnya perhitungan PPh Pasal 21 karyawan PT Istaka Karya (Persero) dengan menggunakan metode gross up. Menunjukan bahwa PPh Pasal 21 metode gross up terdiri dari nama wajib pajak, status wajib pajak, gaji bruto, tunjangan pajak, potongan yang terdiri dari BPJS Ketenagakerjaan sebesar 7,74\%, biaya jabatan (Maksimal potongan sebesar Rp 500.0000, dana pensiun maksimal Rp 200.000, sementara untuk gaji netto merupakan gaji bruto dikurangi dengan total potongan. Gajo netto setahun merupakan jumlah gaji netto dikalikan 12 bulan. Pendapatan Tidak Kena Pajak (PTKP) selama setahun nominalnya ditentukan dari status wajib pajak. Pendapatan Kena Pajak (PKP) selama setahun dihitung dari besarnya gaji netto setahun dikurangi dari PTKP selama setahun. Sehingga perhitungan PPh Pasal 21 setahun dihitung dari persentase $5 \%$ jika penghasilan wajib pajak dengan ketentuan penghasilan selama setahun $1 \mathrm{~s} / \mathrm{d}$ 50 juta rupiah sedangkan 15\% jika penghasilan wajib pajak dengan ketentuan penghasilan selama setahun di atas 50 s/d 250 juta rupiah. Jumlah setoran PPh Pasal 21 sebulan berasal dari PPh Pasal 21 setahun dibagi 12 bulan.

\section{Komparasi metode perhitungan Pajak Penghasilan Pasal 21}

Perbandingan (Komparasi) metode perhitungan Pajak Penghasilan Pasal 21 dengan menggunakan metode gross, net basis dan metode gross up. Berikut adalah komparasi perhitungan Pajak Penghasilan Pasal 21 menggunakan metode gross, metode net basis, dan metode gross up. Berikut tabel komparas metode perhitungan PPh Pasal 21 karyawan PT Istaka Karya (Persero) sejak bulan Januari 2020 sampai dengan Juni 2020.

\section{Tabel 2}

Komparasi Metode Perhitungan PPh Pasal 21

bulan Januari s.d Juni 2020

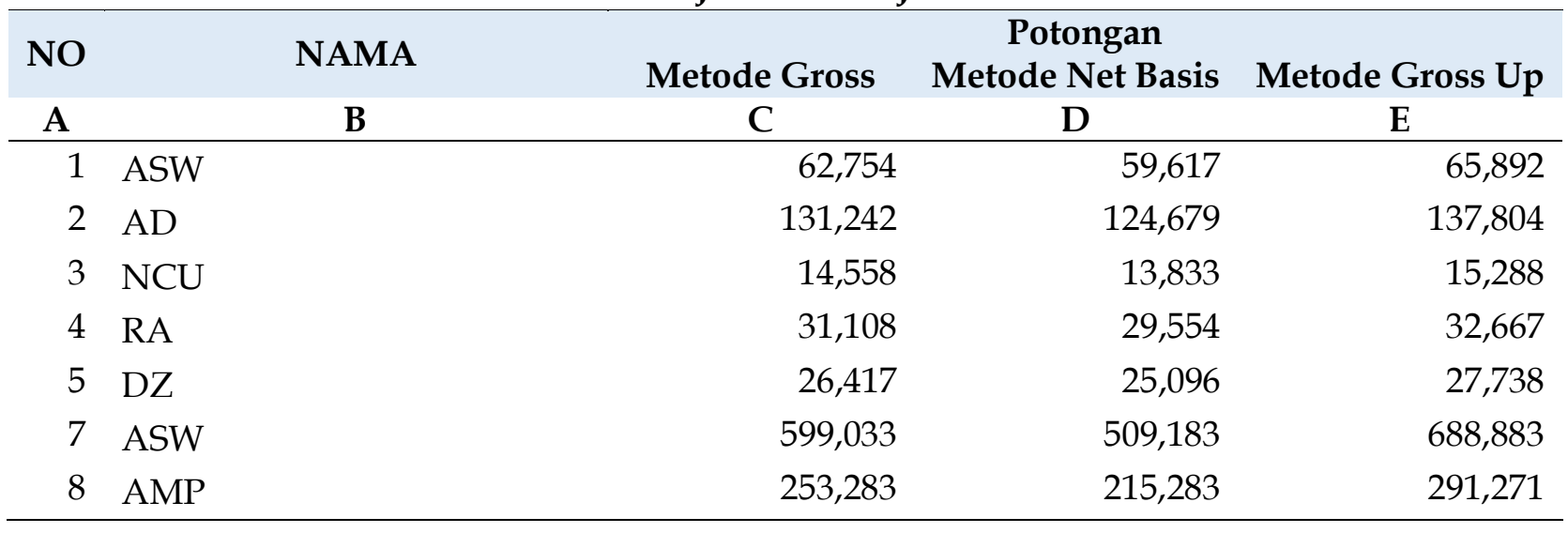




\begin{tabular}{llrrr}
\hline 10 & IY & 130,208 & 123,696 & 136,717 \\
11 & YAT & 73,496 & 69,821 & 77,171 \\
12 & BKA & 346,058 & 294,158 & 397,971 \\
13 & AS & 204,567 & 194,338 & 227,708 \\
14 & ADK & 997,983 & 848,283 & $1,147,671$ \\
16 & RU & $1,642,858$ & $1,396,421$ & $1,889,283$ \\
17 & WP & $2,062,308$ & $1,752,971$ & $2,371,658$ \\
18 & NP & 325,458 & 276,646 & 374,283 \\
19 & AW & 29,500 & 28,025 & 30,975 \\
20 & JM & $1,168,708$ & 993,396 & $1,344,008$ \\
22 & IS & 866,496 & 736,521 & 996,471 \\
23 & HP & $1,327,121$ & $1,128,058$ & $1,526,183$ \\
24 & S & 175,896 & 167,104 & 184,692 \\
25 & EPS & 58,058 & 55,154 & 60,963 \\
26 & M & $1,317,846$ & $1,120,171$ & $1,515,521$ \\
& & JUMLAH & $\mathbf{1 0 , 1 6 2 , 0 0 8}$ & $\mathbf{1 3 , 4 7 8 , 8 6 7}$ \\
\hline
\end{tabular}

Berdasarkan Tabel 2 di atas, menunjukan bahwa jumlah potongan PPh Pasal 21 karyawan PT Istaka Karya (Persero) bulan Januari sampai Juni 2020 metode gross adalah sebesar Rp 11,844,956, metode net basis sebesar 10,162,008, metode gross up sebesar 13,478,867.

\section{Pembahasan}

\section{Penghasilan Karyawan PT Istaka Karya (Persero)}

Ada tiga metode perhitungan PPh pasal 21 yang paling umum digunakan pada perusahaan baik perusahaan yang berskala kecil maupun skal besar terutama pada perusahaan Badan Usaha Milik Negara (BUMN) yaitu Metode gross, Metode net basis, Metode gross up.

Dari ketiga metode di atas PT Istaka Karya (Persero) menggunakan metode gross dalam perhitungan PPh pasal 21, dimana metode ini tarif pajak dibebankan kepada karyawan sebagai wajib pajak. Komponen gaji tetap karyawan pada PT Istaka Karya (Persero0 dalam sebulan terdiri dari gaji dasar, tunjangan struktural, tunjangan fungsional, tunjangan project manager, tunjangan SEM/SOM/SAM, tunjangan pelaksanaan lapangan. Pendapatan lain karyawan terdiri dari : lembur, tunjangan proyek, tunjangan makan dan transportasi. Berikut adalah daftar penghasilan gaji karyawan PT Istaka Karya (Persero) bulan Januari sampai dengan bulan Juni Tahun 2019. Status karyawan pada PT Istaka (persero) terdiri dari Tidak Kawin (TK), Kawin dengan tanpa tanggungan (K0), Kawin dengan tanggungan 1 orang (K1), Kawin dengan tanggungan 2 orang (K2), Kawin dengan tanggungan 3 orang (K3). Metode perhitungan yang digunakan pada PT Istaka Karya (Persero) adalah menggunakan metode gross dalam perhitungan PPh Pasal 21 karyawan. Hal ini dapat dilihat dari daftar perhitungan gaji karyawan, dimana karyawan menanggung sendiri jumlah PPh Pasal 21. 


\section{Metode Perhitungan PPh Pasal 21}

Metode perhitungan PPh Pasal 21 metode gross, pajak ditanggung oleh masingmasing karyawan pada perhitungan pemotongan metode net basis yaitu perusahaan yang menanggung PPh Pasal 21 terutang, akan tetapi dilakukan dengan tidak memperhitungkan $\mathrm{PPh}$ Pasal 21 terutang sebagai unsur tambahan penghasilan. Sedangkan pada perhitungan metode gross up perusahaan menanggung PPh Pasal 21 terutang dengan memberikan tunjangan pajak sebagai unsur tambahan penghasilan.

\section{Komparasi perhitungan PPh Pasal 21}

Perhitungan PPh Pasal 21 dapat digunakan tiga metode yaitu: metode gross, metode net basis dan metode gross up. Metode tersebut masing-masing memiliki keunggulan baik berdasarkan persepektif perusahaan maupun dari perspektif karyawan.

Komparasi perhitungan PPh Pasal 21 karyawan antara metode gross yang digunakan oleh perusahaan dengan metode net dan gross up bulan Januari s.d Juni 2020 yang dapat dilihat pada (Tabel. 3) di atas, yang menunjukan bahwa metode yang paling efisien dari ketiga metode tersebut adalah metode gross up karena dapat menguntungkan kedua belah pihak yaitu dari pihak karyawan maupun dari pihak perusahaan. Namun jika ditinjau dari sisi karyawan terkait jumlah nominal yang harus dibayarkan, maka metode net basis yang lebih tepat digunakan dibandingkan dengan metode gross dan metode gross up. Ditinjau dari perspektif karyawan akan menguntungkan jika perusahaan menggunakan perhitungan pemotongan metode net basis dapat dilihat pada Table 5.10, karena perusahaan akan menanggung PPh pasal 21, tetapi jika dinilai dari sisi perusahaan akan menguntungan jika menggunakan perhitungan pemotongan menggunakan metode gross, karena PPh Pasal 21 akan ditanggung sendiri oleh karyawan PT Istaka Karya (Persero).

\section{KESIMPULAN DAN SARAN}

Berdasarkan hasil penelitian dan pembahasan maka dapat ditarik kesimpulan sebagai berikut: 1). Perhitungan Pajak Penghasilan Pasal 21 PT Istaka Karya (Persero) menggunakan metode gross, yaitu karyawan menanggung sendiri Pajak Penghasilan Pasal 21. 2). Metode yang paling efisien digunakan dalam menghitung Pajak Penghasilan Pasal 21 PT Istaka Karya (Persero) dari ke tiga metode yang dibandingkan adalah metode gross up karena menguntungkan kedua belah pihak yaitu karyawan dan juga perusahaan. Tetapi jika dilihat pada sisi nominal pajak lebih kecil jika perusahaan menggunakan metode net basis.

Saran-saran yang diharapkan bermanfaat baik bagi PT Iska Karya (Persero) yaitu 1). Sebaiknya perusahaan menggunakan metode perhitungan Pajak Penghasilan Pasal 21 metode gross up karena karena akan menguntungkan kedua belah pihak yaitu karyawan dan juga perusahaan. 2) Sebaiknya ketika melakukan perhitungan pada pemotongan atau pemungutan pajak perusahaan lebih teliti dalam menghitung PPh pasal 21 agar tidak terjadi kesalahan-kesalahan dalam pemotongan, penentuan jumlah tanggungan anak, penentuan Pengahasilan Tidak Kena Pajak (PTKP), penyetoran dan pelaporan Pajak Penghasilan Pasal 21 karyawan PT Istaka Karya (persero). 


\section{DAFTAR PUSTAKA}

Arham, M. I. (2016). Analisis Perencanaan Pajak Untuk Pph Pasal 21 Pada Pt. Pegadaian (Persero) Cabang Tuminting. Jurnal EMBA Vol.4(No.1).

Ermaya, A. Y., \& Rantererung, A. S. (2016). Tinjauan Pelaksanaan Pajak Penghasilan Pasal 21 Atas Karyawan Di Pt. Kimia Farma (Persero) Tbk. Plant Bandung. TEDC, Vol.10(No.2 ), 123-128.

Marfiana, A. (2019). Keuntungan Dan Kerugian Penggunaan Metode Gross-Up Dalam Perhitungan Pph Pasal 21 Pegawai Tetap Melalui Analisa Perbandingan. Jurnal Pajak dan Keuangan Negara, Vol.1(No.1), 21-30.

Nabilah, N. N., Mayowan, Y., \& Hapsari, N. N. (2016). Analisis Penerapan Perencanaan Pajak Pph 21 Sebagai Upaya Penghematan Beban Pajak Penghasilan Badan (Studi Kasus Pada Pt Z). Jurnal Perpajakan (JEJAK)|Vol.8(No.1), 1-8.

Resmi, S. (2019). Perpajakan: Teori dan Kasus (Edisi 11 ed.). Jakarta: Salemba Empat.

Rioni, Y. S., Saraswati, D., \& Junawan. (2019). Penerapan Perencanaan Pajak Penghasilan Pasal 21 Sebagai Strategi Penghematan Pembayaran Pajak Pada Yayasan Kurnia. Jurnal Perpajakan, Vol. 1 No. 2 Juli 2019(No.2), 1-11.

Setiawan, H. A. (2017). Penerapan Metode Gross Up Atas Perhitungan Pph Pasal 21 Sebagai Alternatif Efisiensi Pajak. Jurnal Ilmu dan Riset Akuntansi, Volume 6(Nomor 6), 1-22.

Vridag, R. V. D. P. (2015). Analisis Perbandingan Penggunaan Metode Net Basis Dan Metode Gross Up Dalam Perhitungan Pajak Penghasilan Pasal 21 (Pph Pasal 21) Berupa Gaji Dan Tunjangan Karyawan Pt. Remenia Satori Tepas Manado. Jurnal EMBA, Vol. 3(No.4), 306-314. 